\title{
Morphological and biochemical changes in shoot and root organs of common vetch (Vicia sativa L.) after exposure to drought stress
}

\author{
Ramazan Beyaz \\ Department of Soil and Plant Nutrition, Faculty of Agriculture, Kırşehir Ahi Evran University, Kırşehir 40100 Turkey
}

e-mail: ramazanbeyaz@gmail.com

Received 24 Feb 2021

Accepted 22 Jul 2021

\begin{abstract}
Morphological and biochemical responses of shoot and root organs of post-drought stress vetch plant were investigated. Vetch seedlings were exposed to drought stress $\left(100 \mathrm{~g} / 1 \mathrm{PEG}_{6000}\right)$ under in vitro conditions. Parameters were measured on 14-day-old seedlings. Under drought stress, shoot and root length, fresh weight, and water content were decreased. The dry matter ratio (DMR) increased in both the root and the shoot, and an increase in root dry weight was detected. Moreover, drought induced changes in activities of antioxidant enzymes including catalase (CAT), superoxide dismutase (SOD), ascorbate peroxidase (APX), and glutathione reductase (GR) in both organs. Enzymes analysis revealed a reverse association between CAT and SOD with APX and GR activities. The inverse relationship between these antioxidant enzyme activities may depend on the plant's growth period. An increase in proline and malondialdehyde (MDA) contents was detected. Overall, the increase in morphological and biochemical parameters indicates that the root organ had a stronger response than the shoot organ under drought stress. The basic scientific knowledge obtained from this study could benefit future studies, such as breeding, in vetch plants.
\end{abstract}

KEYWORDS: drought $\left(\mathrm{PEG}_{6000}\right)$ stress, in vitro culture, antioxidant enzymes, proline, malondialdehyde (MDA)

\section{INTRODUCTION}

For several benefits, including its high nutritional value as well as its ability to thrive in a wide range of climatic and soil conditions, common vetch (Vicia sativa L.) is among the most grown forage legumes. It could be used for grazing or as a forage crop, exhibiting excellent appeal at all stages of development [1]. Drought is one of the most important abiotic stresses affecting plant growth and crop productivity [2]. Many changes occur at the morphological, physiological, biochemical, and molecular levels in plants due to drought stress [3]. Similar to other stress factors, such as salinity, cold, heavy metals, etc., drought stress causes oxidative stress in plants, and then the stress causes the release of molecules called reactive oxygen species (ROS) (superoxide $\left(\mathrm{O}_{2}^{-}\right)$, singlet oxygen $\left({ }^{1} \mathrm{O}_{2}\right)$, hydroxyl radical $\left(\mathrm{OH}^{\bullet}\right)$, and hydrogen peroxide $\left(\mathrm{H}_{2} \mathrm{O}_{2}\right)$ ) including certain metabolites in plant cells, which are very damaging to different cell compartments [4]. There is an enzymatic and non-enzymatic defense system against these molecules in cells. In this defense system, important basic antioxidative enzymes (e.g., SOD, CAT, APX, and GR) as well as low molecular weight compounds (such as glutathione (GSH), ascorbate (ASC), $\alpha$-tocopherol, carotenoids, glycine-betaine, and proline) are found. All these system elements are biochemical markers given out by the plants in response to the various stress factors involved in drought. These universal biochemical markers provide important basic information about the mechanisms of resistance in plants to various stressors including drought. Although there are some studies $[1,2,5]$ relating to responses of vetch plant to drought stress in different levels: morphological, physiological, biochemical and molecular; little is known about biochemical responses of different organs (shoot and root) of vetch seedling so far. The objective of this study was to determine the morpho-physiological and biochemical changes in the shoot and root of vetch seedlings under drought stress. The basic scientific knowledge obtained from the study could benefit future studies, such as breeding, in vetch plants.

\section{MATERIALS AND METHODS}

Seed surface sterilization, germination of seeds, and application of drought stress under in vitro conditions

The vetch seeds were kept in a 50\% commercial bleach solution (containing 5\% sodium hypochlorite) for $20 \mathrm{~min}$ for surface sterilization and then rinsed 3 times with sterile distilled water. The sterilized seeds were planted into MS [6] basal medium containing 3\% sucrose and solidified with 0.3\% GELRITE. Osmotic stress was induced by adding polyethylene glycol (PEG6000) at a concentration of $100 \mathrm{~g} / \mathrm{l}$ to the basal medium. All the cultures were kept under white fluorescent light $\left(27 \mu \mathrm{mol} \mathrm{m}^{-2} \mathrm{~s}^{-1}\right)$ in a photoperiod of $16 \mathrm{~h}$ and $8 \mathrm{~h}$ of dark at $24 \pm 1^{\circ} \mathrm{C}$. Morphological observations and biochemical analyses were conducted in the shoot and root tissues 14 days after the beginning 
of the cultivation process.

\section{Morphological observations}

Length $(\mathrm{cm})$, fresh-dry weight $(\mathrm{g})$ of shoot and root organs were measured in 10-day seedlings. For measurement of dry weights, samples were placed in a drying oven at $105^{\circ} \mathrm{C}$ for $3 \mathrm{~h}$. The ratio (\%) of dry weight/wet weight was used for calculation of the dry matter (DM). Morphological parameters were measured in three replicates (10 seedlings per repetition) for each (control and drought) treatment.

\section{Water content (WC)}

Water contents (WCs) of shoot and root were calculated following [7]:

$$
\mathrm{WC}=\frac{\text { Fresh weight }- \text { Dry weight }}{\text { Fresh weight }} \times 100 .
$$

\section{Biochemical analyses}

\section{Antioxidative enzyme analysis}

The antioxidative enzyme analysis was performed by modifying the protocol of Kiran et al [8]. Briefly, $0.5 \mathrm{~g}$ of the shoot or root tissue samples was crushed in liquid nitrogen in a porcelain mortar and homogenized with $50 \mathrm{mM}(8 \mathrm{ml})$ potassium-phosphate buffer solution ( $\mathrm{pH} 7.6$ ) containing $0.1 \mathrm{mM}$ Na-EDTA. The homogenized sample was centrifuged at $15000 \mathrm{rpm}$ for $15 \mathrm{~min}$, and the supernatant fraction was then used for the enzyme assay. Homogenized samples were kept at $+4{ }^{\circ} \mathrm{C}$ until the analyses.

\section{SOD activity}

The SOD activity was determined using the method proposed by Çakmak and Marschner [9] and Çakmak et al [10] based on the reduction of NBT (nitro blue tetrazolium chloride) by $\mathrm{O}_{2}^{-}$under the light. The following solutions were orderly added into the reaction medium: $0.1 \mathrm{mM}$ of Na-EDTA containing a $50 \mathrm{mM}$ phosphate buffer ( $\mathrm{pH} 7.6$ ), the enzyme extract (25 to $100 \mu \mathrm{l}$ ), $0.5 \mathrm{ml}$ of $50 \mathrm{mM} \mathrm{Na}_{2} \mathrm{CO}_{3}$ (pH 10.2), $0.5 \mathrm{ml}$ of $12 \mathrm{mM}$ of L-methionine, $0.5 \mathrm{ml}$ of $12 \mathrm{mM} \mathrm{L}$ methionine, $0.5 \mathrm{ml}$ of $75 \mu \mathrm{M}$ p-nitro blue tetrazolium chloride (NBT), and $0.5 \mathrm{ml}$ of $10 \mu \mathrm{M}$ riboflavin. The final volume of the medium was $5 \mathrm{ml}$. All of the samples were kept under light for $15 \mathrm{~min}$ and measured at $560 \mathrm{~nm}$. To essay the SOD, NBT was used to reduce the superoxide radical, which was monitored at $560 \mathrm{~nm}$.

\section{APX activity}

The APX activity was measured using the method proposed by Çakmak and Marschner [9] and Çakmak et al [10] based on the oxidation of ascorbate at $290 \mathrm{~nm}\left(\mathrm{E}=2.8 \mathrm{mM} \mathrm{cm}^{-1}\right)$. By following the method, the final volume of the reaction medium was adjusted to $1 \mathrm{ml}$ by adding $0.1 \mathrm{mM}$ of EDTA containing a $50 \mathrm{mM}$ phosphate buffer (pH 7.6), $0.1 \mathrm{ml}$ of $10 \mathrm{mM}$ of EDTA containing $12 \mathrm{mM}$ of $\mathrm{H}_{2} \mathrm{O}_{2}, 0.1 \mathrm{ml}$ of $0.25 \mathrm{mM} \mathrm{L}(-)$ ascorbic acid and $0.1 \mathrm{ml}$ of the enzyme extract into the medium; and then the ascorbate concentration was measured at $290 \mathrm{~nm}$ (UVmini-1240, SHIMADZU, Japan). One $\mu \mathrm{mol} \mathrm{ml} \mathrm{min}^{-1} \mathrm{~min}^{-1}$ of oxidized ascorbate was defined as one unit of APX activity.

\section{GR activity}

The GR activity was measured using the method proposed by Çakmak and Marschner [9] and Çakmak et al [10] based on the oxidation of NADPH at $340 \mathrm{~nm}\left(\mathrm{E}=6.2 \mathrm{mM} \mathrm{cm}^{-1}\right)$. By following the method, the final volume of the reaction medium was adjusted to $1 \mathrm{ml}$ by adding $0.1 \mathrm{mM}$ of EDTA containing a $50 \mathrm{mM}$ phosphate buffer ( $\mathrm{pH} 7.6), 0.1 \mathrm{ml}$ and $0.5 \mathrm{mM}$ of oxidized glutathione (GSSG), $0.1 \mathrm{ml}$ of $0.5 \mathrm{mM}$ oxidized glutathione (GSSG), $0.1 \mathrm{ml}$ of $0.12 \mathrm{mM} \mathrm{NADPH}$, and $0.1 \mathrm{ml}$ of the enzyme extract into the medium. The absorption of NADPH was then measured at $340 \mathrm{~nm}$ (UVmini-1240, SHIMADZU, Japan), and one $\mu \mathrm{mol} \mathrm{ml}^{-1} \mathrm{~min}^{-1}$ of oxidized NADPH was defined as one unit of GR activity.

\section{CAT activity}

The CAT activity was measured based on the decomposition rate of $\mathrm{H}_{2} \mathrm{O}_{2}$ at $240 \mathrm{~nm}\left(\mathrm{E}=39.4 \mathrm{mM} \mathrm{cm}^{-1}\right)$ $[9,10]$. In the analysis, the final volume of the reaction medium was adjusted to $1 \mathrm{ml}$ by adding $0.1 \mathrm{mM}$ of EDTA containing a $50 \mathrm{mM}$ phosphate buffer ( $\mathrm{pH}$ 7.6), $0.1 \mathrm{ml}$ of $100 \mathrm{mM} \mathrm{H}_{2} \mathrm{O}_{2}$ and $0.1 \mathrm{ml}$ of the enzyme extract into the reaction medium. One $\mu \mathrm{mol} \mathrm{min}^{-1} \mathrm{mg}^{-1}$ of decomposed $\mathrm{H}_{2} \mathrm{O}_{2}$ was defined as one unit of CAT activity.

\section{Measurement of lipid peroxidation (MDA content)}

MDA contents were determined based on the method described by Lutts et al [11]. In short, $5 \mathrm{ml}$ of trichloroacetic acid (TCA) (0.1\%) was added onto a $200 \mathrm{mg}$ sample of fresh shoot or root and then centrifuged at $12500 \mathrm{rpm}$ for $20 \mathrm{~min}$ to separate the supernatant. A sample mixture consisting of $3 \mathrm{ml}$ of the supernatant and $3 \mathrm{ml}$ of $0.1 \%$ thiobarbituric acid in $20 \%$ TCA $(\mathrm{w} / \mathrm{v})$ was prepared. The absorbance was measured at 532 and $600 \mathrm{~nm}$ (UVmini-1240, SHIMADZU, Japan).

\section{Measurement proline content}

The proline assay followed the method of Bates et al [12], by which fresh plant samples were ground with $3 \%$ sulfosalicylic acid. The ninhydrin reagent was added to the tubes containing the ground sample, and the tube was placed in a water bath at $100^{\circ} \mathrm{C}$ for $1 \mathrm{~h}$. After cooling, $4 \mathrm{ml}$ of toluene was added into the sample tube. A measurement at $520 \mathrm{~nm}$ of the sample was taken. 


\section{Statistic analysis}

The study was designed with a completely randomized block design with 3 replications. Data were analyzed using Independent-Samples $t$-test of SPSS 22. Data presented in percentages were subjected to $\operatorname{arcsine}(\sqrt{X})$ transformation before statistical analysis [13].

\section{RESULTS AND DISCUSSION}

Plant reactions to drought stress are very variable. The results of the present study shows that drought stress (100 g/ $1 \mathrm{PEG}_{6000}$ ) caused 33.38\%, 33.33\%, and $11.53 \%(p<0.05)$ decreases in shoot length, shoot fresh, and dry weight, respectively (Table 1). In addition, root length and fresh weight of the root were significantly reduced by $24.84 \%$ and $39.28 \%$, respectively (Table 2 ), but a $16.66 \%$ increase was detected in root dry weight (Table 2). In the dry matter ratio, significant $(p<0.05$ and $p<0.01$ ) increases in both the shoot and the root were seen at $30.53 \%$ and $78.93 \%$, respectively (Tables 1 and 2). On the other hand, decreases of water content (WC) percentages were detected $(p<0.01)$ in both the shoot and the root by $9.37 \%$ and $10.76 \%$, respectively. Various changes in biomass are inevitable in terms of adaptation of the plant under drought stress. In the study of plant adaptation processes (avoidance or tolerance) in reaction to water deficit conditions, the dynamics of the shoot and the root adjustments are considered as a significant parameter [14]. The results of this study showed that significant changes occurred in basic biomass parameters in both organs, and they are consistent with other previously reported findings [15-17].

At the initial stage of plant growth and establishment, water stress was a very significant limiting factor. It has been determined that the dry matter ratio in both shoot and root increases under drought stress (Tables 1 and 2). Similarly, it has been reported that drought increases the percentage of shoot and root dry matter ratio in many plant species such as grass pea [18] and common bean [14]. The translocation of dry matter to roots promotes root development and ultimately enhances the water retaining capacity of the plant [14], hence, indicating the root's adaptation ability to drought stress.

According to the results of the present study, there were decreases in WCs in both the shoot and the root, with more in the root (Tables 1 and 2). The results were in line with Zheng et al [7] who reported that the WCs in the root and shoot organs of winter wheat cultivars were decreased under the stress factor (salt).

Drought stress in plants induces many physiological and biochemical changes, making the maintenance of osmotic adjustment extremely necessary [19]. In addition, acid rain, another abiotic stress, was shown to cause a decrease in root/shoot length ratio and seed germination in rice [20]. Among all the changes, the most important ones involve enzymes and osmoregulation, which are the main components of the antioxidant defence mechanism. In this study, the activities of antioxidant enzymes (APX, CAT, GR, and SOD), MDA, and proline content in the shoot and the root were investigated. Under drought stress, CAT and SOD activities significantly increased by $27.77 \%$ and $25.31 \%$ in shoot; and $50.84 \%$, and $43.76 \%$ in root, respectively (Tables 3 and 4). On the other hand, APX and GR activities significantly decreased by $0.86 \%$ and $9.77 \%$ in shoot; and $1.74 \%$ and $3.58 \%$ in root, respectively. Drought-induced metabolism deregulation increases the generation of reactive oxygen species (ROS), which in turn affects the cell's redox regulatory condition [21]. Plant cells, therefore, need various mechanisms that will allow excess ROS to be detoxified and keep the ROS formation and removal in balance [16]. The enzyme that takes the first step in converting superoxide to hydrogen peroxide $\left(\mathrm{H}_{2} \mathrm{O}_{2}\right)$ is SOD. The $\mathrm{H}_{2} \mathrm{O}_{2}$ are then broken down by the CAT enzyme. CAT is one of the key enzymes in peroxidases that scavenge dangerous oxygen species in plants. According to the present study, the activities of SOD and CAT significantly $(p<0.01)$ increased in shoot and root (Tables 3 and 4). However, the increase seems to be higher in the root. It is thought that the activities of these enzymes are more in the root, as the root encounters the stress factor more intensely. Indeed, antioxidant enzyme responses differ among plant species, organ, and even in diurnal. However, it has been reported in previous studies that abiotic stress factors (such as drought) cause significant changes in the response of antioxidant enzyme mechanisms including CAT and SOD [5, 22, 23].

The four enzymes: APX, GR, monodehydroascorbate reductase (MR), and dehydroascorbate reductase (DR); of the ascorbate-glutathione cycle (AsAGSH cycle) are the key components that scavenge $\mathrm{H}_{2} \mathrm{O}_{2}$, the result of SOD dismutation of $\mathrm{O}_{2}$, in various cell compartments [24]. Many studies in the literature have reported that among these four important enzymes, the activities of APX and GR increase under drought stress [22, 25, 26]. However, interestingly, in the present study, a decrease in the activities of the two enzymes was found in both the shoot and the root organs (Tables 3 and 4). Mohammadkhani and Heidari [27] found decreation in APX activity under drought stress in roots and shoots of maize cultivars. Antioxidant enzyme responses can be very different depending on different stress factors, stress doses, the time of application of the stress factor, different plant genotypes and/or varieties, even different organs of the plant. The results of this study prove this statement.

It is appeared to be a negative relationship between SOD and CAT with APX and GR enzymes in both organs. According to Terzi and Kadıŏlu [28], under 
Table 1 Changes in morpho-physiological parameters of the shoot of vetch seedlings under drought stress (100 g/1 PEG 6000$)$.

\begin{tabular}{|c|c|c|c|c|c|c|c|c|c|c|}
\hline & \multicolumn{2}{|c|}{ Length (cm) } & \multicolumn{2}{|c|}{ Fresh weight (g) } & \multicolumn{2}{|c|}{ Dry weight (g) } & \multicolumn{2}{|c|}{ Dry matter (\%) } & \multicolumn{2}{|c|}{ Water Content (\%) } \\
\hline & Cont. & Drought & Cont. & Drought & Cont. & Drought & Cont. & Drought & Cont. & Drought \\
\hline & 7.04 & 4.69 & 1.14 & 0.76 & 0.26 & 0.23 & 23.48 & 30.65 & 76.51 & 69.34 \\
\hline$t$-value & \multicolumn{2}{|c|}{$3.054^{*}$} & \multicolumn{2}{|c|}{$3.268^{*}$} & \multicolumn{2}{|c|}{$3.257^{*}$} & \multicolumn{2}{|c|}{$3.596^{*}$} & \multicolumn{2}{|c|}{$11.148^{* * *}$} \\
\hline
\end{tabular}

*, ** Significant difference $(p<0.05$ and $p<0.01)$ compared to control; Cont. = Control.

Table 2 Changes in morpho-physiological parameters of the root of vetch seedlings under drought stress (100 g/l PEG 6000$)$.

\begin{tabular}{|c|c|c|c|c|c|c|c|c|c|c|}
\hline & \multicolumn{2}{|c|}{ Length (cm) } & \multicolumn{2}{|c|}{ Fresh weight (g) } & \multicolumn{2}{|c|}{ Dry weight (g) } & \multicolumn{2}{|c|}{ Dry matter (\%) } & \multicolumn{2}{|c|}{ Water Content (\%) } \\
\hline & Cont. & Drought & Cont. & Drought & Cont. & Drought & Cont. & Drought & Cont. & Drought \\
\hline & 4.87 & 3.66 & 0.56 & 0.34 & 0.06 & 0.07 & 12.01 & 21.49 & 87.98 & 78.51 \\
\hline$t$-value & \multicolumn{2}{|c|}{$13.112^{* * *}$} & \multicolumn{2}{|c|}{$4.430^{* * *}$} & \multicolumn{2}{|c|}{$2.230^{*}$} & \multicolumn{2}{|c|}{$5.508^{* * *}$} & \multicolumn{2}{|c|}{$17.218^{* * *}$} \\
\hline
\end{tabular}

$*$, ** Significant difference $(p<0.05$ and $p<0.01)$ compared to control; Cont. = Control.

drought stress, there is no consistent finding in the literature regarding antioxidant enzyme activities such as SOD, GR, and POD. Therefore, it is difficult to explain the inverse relationship between these enzymes. However, according to these data, it can be said that SOD and CAT enzymes are very active in both organs in reduction of oxidative stress caused by drought stress. Besides, it has been reported that the number of some antioxidant enzymes is not sufficient to eliminate the excessive amount of reactive oxygen species formed as a result of excessive lipid peroxidation triggered by drought stress [29]. In our study, we observed an excessive amount of MDA production in both the shoot $(17.86 \%)$ and the root (305.21\%). Therefore, in this context, the reason for the decrease of APX and GR can be due to their insufficiency in eliminating the excessive amount of reactive oxygen species (ROS) formed as a result of oxidative stress triggered by drought.

ROS induce lipid peroxidation giving rise to MDA as an indicator for membrane damages especially during drought [21]. Under drought stress, the present study result showed that there was an increase in MDA content in both the shoot and the root of $17.86 \%$ and $305.21 \%$, respectively, when compared with the control group (Tables 3 and 4). Parallel to this result, Mohammadkhani and Heidari [27] reported that the increase in content of MDA depended on the intensity of water stress in the shoot and the root organs of maize. In addition, Gua et al [23] noticed that the accumulation of MDA in shoot and root of Lycium ruthenicum seedlings increased with increasing drought stress level. Zhang et al [21]. Moreover, Beyaz [5] reported similar results in sainfoin. Our results show that MDA accumulation is greater in the shoot than the root (Tables 3 and 4). These findings have also been confirmed by the studies of Beyaz [5], Gua et al [23], and Mohammadkhani and Heidari [27]. This result may be explained by the less effective antioxidant defence capacity in shoot compared to the

Table 3 Changes in biochemical parameters of the shoot of vetch seedlings under drought stress (100 g/l PEG 6000$)$.

\begin{tabular}{|c|c|c|c|c|c|c|c|c|c|c|c|c|}
\hline & \multicolumn{2}{|c|}{ APX } & \multicolumn{3}{|c|}{ 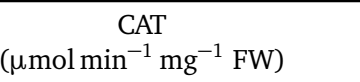 } & GR & \multicolumn{2}{|c|}{$\begin{array}{c}\text { SOD } \\
\left(\mathrm{U} \mathrm{min}^{-1} \mathrm{mg}^{-1} \mathrm{FW}\right)\end{array}$} & \multicolumn{4}{|c|}{$\begin{array}{l}\text { MDA } \\
\quad\left(\mu \mathrm{mol} \mathrm{g}^{-1} \mathrm{FW}\right)\end{array}$} \\
\hline & Cont. & Drought & Cont. & Drought & Cont. & Drought & Cont. & Drought & Cont. & Drought & Cont. & Drought \\
\hline & 224.38 & 222.44 & 162.43 & 207.55 & 163.73 & 147.73 & 325.08 & 407.36 & 6.39 & 16.87 & 3.47 & 4.09 \\
\hline$t$-value & \multicolumn{2}{|c|}{$3.715^{*}$} & \multicolumn{2}{|c|}{$7.645^{* * *}$} & \multicolumn{2}{|c|}{$5.114^{* * *}$} & \multicolumn{2}{|c|}{$11.192^{* * *}$} & \multicolumn{2}{|c|}{$13.823^{* * *}$} & \multicolumn{2}{|c|}{$3.308^{* * *}$} \\
\hline
\end{tabular}

$*$, ** Significant difference $(p<0.05$ and $p<0.01)$ compared to control; Cont. = Control.

Table 4 Changes in biochemical parameters of the root of vetch seedlings under drought stress $\left(100 \mathrm{~g} / 1 \mathrm{PEG}_{6000}\right)$.

\begin{tabular}{|c|c|c|c|c|c|c|c|c|c|c|c|c|}
\hline & \multicolumn{2}{|c|}{ APX } & \multicolumn{3}{|c|}{$\begin{array}{c}\text { CAT } \\
\left(\mu \mathrm{mol} \mathrm{min}{ }^{-1} \mathrm{mg}^{-1} \mathrm{FW}\right)\end{array}$} & GR & \multicolumn{2}{|c|}{$\begin{array}{c}\text { SOD } \\
\left(\mathrm{U} \mathrm{min}^{-1} \mathrm{mg}^{-1} \mathrm{FW}\right)\end{array}$} & \multicolumn{4}{|c|}{$\begin{array}{l}\text { MDA Proline } \\
\left(\mu \mathrm{mol} \mathrm{g}^{-1} \mathrm{FW}\right)\end{array}$} \\
\hline & Cont. & Drought & Cont. & Drought & Cont. & Drought & Cont. & Drought & Cont. & Drought & Cont. & Drought \\
\hline & 227.12 & 223.16 & 159.73 & 240.94 & 163.82 & 157.95 & 366.73 & 527.24 & 3.26 & 13.21 & 5.59 & 17.51 \\
\hline$t$-value & \multicolumn{2}{|c|}{$3.263^{* * *}$} & \multicolumn{2}{|c|}{$5.303^{* *}$} & \multicolumn{2}{|c|}{$4.293^{* * *}$} & \multicolumn{2}{|c|}{$6.909^{* * *}$} & \multicolumn{2}{|c|}{$3.800^{*}$} & \multicolumn{2}{|c|}{$6.493^{* * *}$} \\
\hline
\end{tabular}

$*, * *$ Significant difference $(p<0.05$ and $p<0.01)$ compared to control; Cont. $=$ Control. 
root. However, many studies $[16,28]$ have reported an increased accumulation of MDA in plants under drought stress.

Proline is one of the most effective organic solvents that, by acting as osmoprotectants for membrane stabilization, preserve the water content under stressful conditions [23]. In this study, it was found that under drought stress, proline accumulation in the shoot and the root of vetch seedlings increased by $164.00 \%$ and $213.23 \%$, respectively, when compared with the control group (Tables 3 and 4). Similar to our results, an increase in the amount of proline in different plants organs (shoot and root) under drought stress has been reported in many other studies [5, 22, 23]. The increase in proline accumulation was associated with the decrease in plant relative water content [16]. Our results show that not only in the shoot, but also in the root the relative water content decreased while the amount of proline increased (Tables 1-4). For most plants, the improvement of proline synthesis was a tactic to thrive and continue to develop underwater deficiency [14].

\section{CONCLUSION}

In conclusion, the results of the present study showed that drought stress has a marked influence on morphological, physiological, and biochemical parameters of both shoot and root organs in vetch seedlings. All parameters examined in the shoot and the root under drought $\left(100 \mathrm{~g} / 1 \mathrm{PEG}_{6000}\right)$ stress are directly consistant to the literature knowledge. However, unlike the literature knowledge, the results of this study showed that activities of the two antioxidant enzymes, APX and GR, decreased in both the shoot and the root. Besides, it seemed that SOD and CAT were dominant for both organs. Therefore, it is recommended that more biotechnological studies should be done on how to enhance the activity of the APX and GR enzymes to increase the tolerance to drought stress in vetch. This is the first report to note changes in morphophysiological and biochemical traits under drought stress in organs of vetch.

Acknowledgements: This study was conducted by laboratory and growth chamber facilities of the Biotechnology Institute of Ankara University (Ankara, Turkey). The author is grateful to the manager of this institute for their cooperation.

\section{REFERENCES}

1. Abbasi AR, Sarvestani R, Mohammadi B, Baghery A (2014) Drought stress-induced changes at physiological and biochemical levels in some common vetch (Vicia sativa L.) genotypes. J Agr Sci Tech 16, 505-516.

2. Abbasi AR, Mohammadi B, Sarvestani R, Mirataei F (2015) Expression analysis of candidate genes in common vetch (Vicia sativa L.) under drought stress. J Agr Sci Tech 15, 1291-1302.

3. Senakoon W, Nuchadomrong S, Jearranaiprepame P, Senawong G, Jogloy S, Songsri P (2021) Aspergillus flavus virulence in pods and seeds of peanut with different drought responsive genotypes related to water status. ScienceAsia 47, 178-186.

4. Xue-Tao Y, Fu-Ping L, Hai-Hong G (2020) Effects of high temperature on photosynthetic capacity in the leaves of creepers. ScienceAsia 46, 436-443.

5. Beyaz R (2019) Biochemical responses of sainfoin shoot and root tissues to drought stress in in vitro culture. Legum Res 42, 173-177.

6. Murashige T, Skoog F (1962) A revised medium for rapid growth and bioassays with tobacco tissue cultures. Physiol Plant 15, 473-497.

7. Zhenga Y, Jiac A, Ning T, Xu J, Li Z, Jiang G (2008) Potassium nitrate application alleviates sodium chloride stress in winter wheat cultivars differing in salt tolerance. $J$ Plant Physiol 165, 1455-1465.

8. Kiran S, Kuşvuran S, Özkay F, Ellialtioğlu SS (2019) Change in physiological and biochemical parameters under drought stress in salt-tolerant and salt-susceptible eggplant genotypes. Turk J Agric For 43, 593-602.

9. Cakmak I, Marschner H (1992) Magnesium deficiency and high light intensity enhance activities of superoxide dismutase, ascorbate peroxidase and glutathione reductase in bean leaves. Plant Physiol 98, 1222-1226.

10. Çakmak I, Atlı M, Kaya R, Evliya H, Marschner H (1995) Association of high light and zinc deficiency in coldinduced leaf chlorosis in grapefruit and mandarin trees. J Plant Physiol 146, 355-360.

11. Lutts S, Kine JM, Bouharmont J (1996) NaCl-induced senesence in leaves of rice (Oryza sativa L.) cultivars differing in salinity resistance. Annual Botany 78, 389-398.

12. Bates LS, Waldren RP, Teare ID (1973) Rapid determination of free proline for water stress studies. Plant Soil 39, 205-207.

13. Snedecor GW, Cochran WG (1980) Statistical Methods, 7th edn, Iowa State Univ Press, Iowa, USA.

14. Widuri LI, Lakitan B, Sodikin E, Hasmeda M, Meihana M, Kartika K, Siaga E (2018) Shoot and root growth in common bean (Phaseolus vulgaris L.) exposed to gradual drought stress. Agrivita J Agric Sci 40, 442-452.

15. Santos R, Carvalho M, Rosa E, Carnide V, Castro I (2020) Root and agro-morphological traits performance in cowpea under drought stress. Agronomy 10, ID 1604.

16. Kavas M, Baloğlu MC, Akça O, Köse FS, Gökçay D (2013) Effect of drought stress on oxidative damage and antioxidant enzyme activity in melon seedlings. Turk $J$ Biol 37, 491-498.

17. Yan C, Song S, Wang W, Wang C, Li H, Wang F, Li S, Sun $X$ (2020) Screening diverse soybean genotypes for drought tolerance by membership function value based on multiple traits and drought-tolerant coefficient of yield. BMC Plant Biol 20, ID 321.

18. Iseki K, Takahashi Y, Muto C, Naito K, Tomooka N (2018) Diversity of drought tolerance in the genus Vigna. Front Plant Sci 9, ID 729.

19. Ozturk M, Unal BT, García-Caparrós P, Khursheed A, Gul A, Mirza H (2020) Osmoregulation and its actions during the drought stress in plants. Physiol Plant 172, 1321-1335.

20. Sreesaeng J, Kongchiu P, Nakasathien S (2021) Preliminary responses of some Thai rice cultivars to simulated acid rain stress during seed germination. ScienceAsia 47, 303-311. 
21. Laxa M, Liebthal M, Telman W, Chibani K, Dietz KJ (2019) The role of the plant antioxidant system in drought tolerance. Antioxidants 8, ID 94.

22. Zhang L, Peng J, Chen TT, Zhao XH, Zhang SP, Liu SD, Dong HL, Feng L, et al (2014) Effect of drought stress on lipid peroxidation and proline content in cotton roots. $J$ Anim Plant Sci 24, 1729-1736.

23. Guo YY, Yua HY, Yang MM, Konga DS, Zhang YJ (2018) Effect of drought stress on lipid peroxidation, osmotic adjustment and antioxidant enzyme activity of leaves and roots of Lycium ruthenicum Murr. seedling. Russ $J$ Plant Physiol 65, 244-250.

24. Asada K (1999) The water-water cycle in chloroplasts: scavenging of active oxygens and dissipation of excess photons. Annu Rev Plant Physiol Plant Mol Biol 50, 601-639.

25. Lou L, Li X, Chen J, Li Y, Tang Y, Lv J (2018) Photosynthetic and ascorbate-glutathione metabolism in the flag leaves as compared to spikes under drought stress of winter wheat (Triticum aestivum L.). PLoS One 13, ID 0194625.

26. Mittler R, Zilinskas BA (1994) Regulation of pea cytosolic ascorbate peroxidase and other antioxidant enzymes during the progression of drought stress and following recovery from drought. Plant $J$ 5, 397-405.

27. Mohammadkhani N, Heidari R (2007) Effects of drought stress on protective enzyme activities and lipid peroxidation in two maize cultivars. Pak J Biol Sci 10, 3835-3840.

28. Terzi R, Kadioglu A (2006) Drought Stress tolerance and the antioxidant enzyme system in Ctenanthe setosa. Acta Biol Cracov Bot 48, 89-96.

29. Zhang X, Yang Z, Li Z, Zhang F, Hao L (2020) Effects of drought stress on physiology and antioxidative activity in two varieties of Cynanchum thesioides. Braz J Bot 43, $1-10$. 